\title{
Legal Impact on People Died in Kasepekang Sanction
}

\author{
Ni Made Trisna Dewi \\ Fakultas Hukum, Universitas Dwijendra, Denpasar-Indonesia \\ madetrisnadewishmh@gmail.com
}

Published: 25/02/2021

\begin{abstract}
How to cite:
Dewi, N. M. T. (2021). Legal Impact on People Died in Kasepekang Sanction. Sociological Jurisprudence Journal. 4(1). Page 54 - 60. https://
\end{abstract} doi.org/10.22225/scj.4.1.2287.54-60

\begin{abstract}
The Pakraman village is led by village officers. The issue of how to implement the Kasepekang sanction is very important to analyse because fraud or abuse of power often occurs in this sector. Kesepekang the term of traditional sanctions in the form of a temporary dismissal as a member of the banjar and pakraman villages. Those affected by this sanction are not entitled to receive banjar service / assistance and pakraman villages. This type of research is empirical legal research oriented to the collection of empirical data in the field. Based on this empirical data the researcher conducted an in-depth analysis in accordance with the relevant theory to make conclusions. Kasepekang sanctions are given because community members do not want to solve and conduct paruman to find solutions to adat problems. Based on paruman adat leaders and community representatives prescribed on Awigawig Number 18, paragraph 14 regarding unwritten regulations, it was decided by the village of Pakraman Pempatan and it was agreed that the person be subject to a sanction of being left unchecked. This case was motivated by civil problems continued with the existence of actions and reactions, developed into a criminal problem that is the desecration of the holy place and customary matters.
\end{abstract}

Keywords: Pekraman Village, Law, Kesepekang Sanction

\section{INTRODUCTION}

In Pakraman Village, there are conflicts between customary villages and their citizens. There are times when adat shows an attitude that is said to be arrogant in imposing sanctions on its citizens. This arrogance is shown, among others, by the violent attitude that often accompanies the application of sanctions, even though this attitude is contrary to the traditional way of life. It teaches that every problem is resolved by deliberation based on the principles of harmony, and appropriateness (Tjok Istri Putra Astiti, 2010: 9). The administration of the Pakraman village government is led by village officers. The structure of village officers generally consists of the village as the leader, the withdrawal as the secretary, the patengen as treasurer, and the Kasinoman as general aide or direction (I Nyoman, Sirtha 2008: 4). Kesepekang, the term of traditional sanctions in the form of a temporary dismissal as a member of the Banjar (community member) and pakraman villages, so that those affected by this sanction are not entitled to receive service/assistance from banjar and pakraman villages. This is marked by not getting the Banjar bell called Kulkul.

In Kasepekang sanctions or other terms that contain the same meaning as temporary dismissal for village karma. This can be imposed on the basis of banjar or pakraman village to manners which are proven convincingly to disobey awig-awig(traditional law agreed by the banjar member), pararem (banjar regulation), and the banjar or pakraman agreement (I Nyoman, Sirtha 2008: 20). Kesepekang is one of a number of traditional sanctions known in the Balinese Customary Law. Penalty sanctions are imposed on residents deemed to have committed certain traditional violations. Kasepekang adat sanctions are most famous due to the prohibition of burial, the emergence of internal village conflicts and the emergence of pro and contra discourses immediately after sanctions were imposed (Wayan P. Windia, 2008: 22). Law number 23 of 2014 concerning regional government, article 1 number 12, 
namely the Autonomous Region, hereinafter referred to as the Region, is a legal community unit that has territorial boundaries authorized to regulate and administer Government Affairs and the interests of local communities according to their own initiatives based on community aspirations in system of the Unitary Republic of Indonesia.

The effectiveness of law in legal action is known when someone states that a rule of law is successful or fails to reach its goal. It is usually known whether the effect is successful in regulating certain behavioral actions or behaviors is in line with its objectives or not. Regarding the issue I discussed about the customary (adat) sanctions, this occurs when customs are apathetic in participating in various activities or activities in Pakraman village, and besides that customary manners never pay dedosions (fines). When this happens, those affected by these sanctions are not entitled to budgeting service/ assistance from Pakraman village. This is one of the causes of the conflict between Pakraman village and its residents occurred in Pakraman village in Pempatan, Rendang district, Karangsem regency. The theory of legal effectiveness explains the operation of a statutory regulation when applied in society (Soerjono Soekanto, 1983: 80). Understanding effectiveness is how well the work is done, to what extent people produce output as expected. This means that if a job can be completed in accordance to the planning, both in time, cost and quality, then it can be said to be effective (Ravianto. 1989: 113).

One effort that is usually done for people to adhere the rule of law is to include sanctions. These sanctions can be in the form of negative sanctions or positive sanctions, the purpose of which is to create a stimulus so that people do not take despicable actions or take commendable actions. Certain conditions must be met so that the law has an influence on human behavior. One of these conditions is that the law must be communicated. Legal communication is more focused on attitude, because attitude is a mental readiness. This implies for someone to have a tendency giving a good or bad view, which then manifests in real behavior. If that is communicated well, it can not solve the problems directly and will encounter more difficulties. The result is that the law has no influence at all or even has a negative impact due to the needs are not met and understood, resulting in frustration, pressure, or even conflict.

Bali Customary Law is a complex of norms, both in written and unwritten form, containing commands, permits and prohibitions, which regulate the life of the Balinese people. This customary law concerns the relationship between human beings, human relations with nature, and the relationship between humans and their Lord. The purpose of law is the purpose of life itself, namely the creation of the well-being of mankind, which is translated as life "sukerta sekala niskala". In Balinese concept, to achieve these life goals, harmony must always be maintained and endeavored for a balance of relationships between human beings, the relationship between humans and nature, and the relationship between humans and God. If the harmony of this relationship is disturbed, there must be efforts or legal actions to restore the balance. This might be implemented in the form of customary reactions or customary sanctions (Windia and Sudantra, 2006: 6). Violation of customs (adat) or religion (which has not been accepted as law), only in the case of violations that carry a general danger in economic hazard for the ruling class in society and it is very large for the defense of public order, then the government acts against the violators or by other words in the case of violations of customs (customs) or religion (Utrecht, E. 1966: 120). The purpose of imposing adat sanctions must follow the philosophy of customary dispute resolution. The sanctions applied must support the purpose of resolving disputes or cases in a customary manner. The customary philosophy of resolving disputes or cases is different from resolving disputes or cases in the formal courts. On the contrary, customary dispute or case resolution is not solely for that, but rather to restore the peace and harmony of the community. After resolving traditionally, the parties to the dispute will make up again as before, the perpetrators of adat violations will return to being part of the community and can live in harmony again with the community (Utrecht, E. 1966: 122).

Customary Law in the Criminal Code (KUHP) has no recognition. Law of the Republic of Indonesia Number 23 Year 2014, Regarding Regional Government, Article 1 paragraph 12, namely Autonomous Region, hereinafter referred to as Region, is a legal community unit that has territorial boundaries authorized to regulate and administer Government Affairs and the interests of local communities according to their own initiatives based on aspirations community in the system of the Unitary Republic of Indonesia. Article 13 (Independent Statements) the distribution of concurrent governmental affairs between the central government and the provincial and district/city regions is based on the principle of 
accountability, efficiency and externality, as well as national strategic interests. TAP MPR S/111960 is the stem of the role of customary law in the development of national law. Fostering national law in accordance with State law and based on Customary Law Article 1 paragraph 4 of the Draft Law of the Criminal Code explains the application of the law that lives in the community as long as it is in accordance with the values of the Pancasila and/or general legal principles recognized by the people of the nations. Emergency Law No. 1 Year 1951 concerning the position of criminal law is actually a law on temporary measures to organize a unitary arrangement of powers and civil court proceedings. Village Court Concept Article 3a RO Emergency Law Number 1 Year 1951 concerning temporary measures to organize a unitary arrangement power and civil court proceedings. All events do not arise due to the actions of legal subjects, but if they occur, this can have certain legal consequences. Legal consequences are all consequences that occur from all legal actions carried out by legal subjects to the law or other consequences caused by certain events. It has been determined by the law itself and is considered as a legal consequence. In short, legal consequences can be interpreted as the result of a legal action. These legal consequences are the rights and obligations for legal subjects.

Legal consequences are a result caused by the law, on an act carried out by legal subjects (Achmad Ali, 2008: 192). Legal aspects are all things that are subject to legal arrangements in which all rights and obligations as well as powers of legal subjects are related in them. Legal works are any human actions that are done intentionally to give rights and obligations. Legal action is the action of a legal subject whose perpetrators act the law. There are legal acts of law as the actions of legal subjects and there are also acts against the law. Acts against the law in Article 1365 of the Civil Code states: "Every act that violates the law, which brings harm to others, requires that those who by mistake publish the loss compensate the loss" (Rahardjo, Satjito, 2012: 95). Rights are two things that can not be separated, both of which have a close relationship. This means that when there are rights that can be obtained, there are also obligations must be exercised. Article 570 of the Civil Code states that the right of ownership is the right to enjoy the use of a material in any way as long as it does not have conflict with the laws or general regulations established by a power that has the right to determine, and does not interfere with the rights of others.

\section{METHOD}

The scientific method is a procedure in gaining knowledge called science. Knowledge is gained through scientific methods and scientific result is obtained in a systematic interrelation (Sunggono Bambang, 2007: 44). Research is basically a scientific activity based on certain methods and thoughts aimed at studying one or several specific phenomena clearly and analyzing it in-depth examination for a solution to the problems that arise in the symptoms concerned (Sunggono Bambang, 2007: 38). This empirical research is field research which oriented to the collection of empirical data in the field. In this study the theories of regulatory provisions, legal norms, doctrines, and previous research reports have been considered sufficietly, so the hyphotesis is no longer required for this research (Fakultas Hukum, Universitas Udayana, 2013: 81). The data used in this study are primary data and secondary data. Primary data is data sourced from field research. It is data obtained directly from the first source in the field both from respondents and informants. Secondary data sourced from library research.

Data collection technique used is the interview technique. Interview technique is one of the techniques often used in impirical legal research. Besides primary data, there are secondary data needed to support the data analysis. Qualitative data is data about qualities described in words and nonnumerical in nature. It is usually collected through field notes, documentation study, in-depth interviews or participatory observation and it is obtained through a qualitative approach (Mohammad Ali and Muhammad Asrosi, 2014: 287). Interview is a form of verbal communication or of conversation aims to obtain information (Nasution, S. 2014: 113).

\section{RESULT AND DISCUSSION}

When a member of local hindu community is not involved in social service, e.g. clean up the gutter due to overtime work in a company, many other members of Banjar or villagers are angry and propose for the person to be left unharmed, kesepekang. He must be punished. Every member of local community called Banjar has problems with their work and what is called ngayah (social service) in the concept of tradititional way of village life (adat) is not the same as labor force. Ngayah must be seen 
from the element of sincerity. Manyama-braya (traditional way of the local life) in the scope of villages is to understand the problems faced by villagers and then apply the concepts of mutual respect, compassion and fostering. Indeed, there is no such thing in a traditional village, no matter what the case is. It is strange that fellow villagers who have lived together in the village for years punish each other. But, on the other hand, being so tolerant to migrants. Isn't Kasepekang not like house arrest, city arrest and body arrest? Nobody is arrested and restricted. There are only sanctions of adat law, and that is also customary sanctions where the condemned is registered as an indigenous citizen. In Bali adat is more gripping than religion. Adat has also regulated the life and death of Balinese Hindu. The matter of life is related to worship, Pura Kahyangan Tiga is related to adat and the dead are related to graves, which belongs to traditional village. When adat institutions remain rigid, it is the religious institutions must break them down. The solution is, by establishing Jagatnatha Temple at least in every regency, so that people can live and pray without custom bulkhead (Sirtha I Nyoman, 2008.:134). As a Balinese person and administrator of the Central Parisada, I have concerned with adat cases for long time, especially "Kasepekang law". This is law outside the legal norms of modern society.

Kesepekang does not concern the body, because there is no detention. It also does not involve the house because it can leave the house freely. The Kesepekang is that the person is excluded from the adat life, or for the less stricted adat law, it is deactivated from the adat village until 'the condemned' pays the fine. For villages that are classified as "a very strict", villagers are prohibited from talking to kasepekang people. Even the lonely are forbidden to pretend to pray. When examined, this punishment has violated aspects of human rights, legal adjustments must take place in accordance with the times, although it will be in contact with culture but what must be understood is that culture is also created by humans themselves. The Bali Pakraman Village Assembly issued Decree Number 01 / Kep / Psm 2 / MDP Bali / X / 2007 stated that "Imposition of customary sanctions for kesepekang and kanorayang, temporarily banned waiting for an adequate formulation of the understanding and procedures for imposing adat sanctions, which applies to all Desa Pakraman in Bali. For Adat law in Bali, a punishment may be imposed without giving the person the opportunity to defend themselves. Moreover, this law can be imposed by a majority vote. Samuhan Agung or the working meeting of the Bali Pekraman Village Assembly (MUDP) decided that the customary village (Desa Adat) should straighten out the imposition of punishments on residents who are considered to violate the adat agreement. Kasepekang or temporary dismissal as a villager, in practice is considered to violate human rights. For example, the practice of prohibiting the use of graves and temples for residents under the charge of kasepekang sanctions. The Bali Pekraman Village Assembly (MUDP) decides the imposition of a kasepekang punishment only as a suspension without expulsion from the village. These kasepekang residents still have the right to use the banjar or village or grave yard for the corpse and make use of the holy places or temples with the knowledge of village officials. In addition to being kasepekang, MUDP also asked desa adat not to impose sanctions on permanent or canalization of citizens. In his decision, the office can only sentence the kasepekang villager to a maximum of three years when the residents act out very serious crimes.

Discussion of the commissions in the Office of the Governor of Bali, Renon, on Friday (10/15, 2015), Pasamuhan Agung participants criticized the adverse effects of the Kasepekang which has become a polemic. So far, Bali has tended to neutralize customary rules and thus is reluctant to change them, including kasepekang sanctions can violate human rights. In addition to being in conflict with human rights, a number of the management of the Bali Pekraman Village Assembly (MUDP) also concerned about the loss of young people and indigenous people due to the severity of adat law. "Don't be a dictator, Pakraman Village. Do not just because of personal family problems, kasepekang sanctions are applied to the member of the Banjar. Our citizens can be exhausted because they do not want to become a member of traditional community, "said Ida I Dewa Ngurah Suwastha, Deputy Chairperson of Bali Pekraman Village Assembly. If there are traditional villages impose kasepekang punishment without giving citizens rights, then it is considered as a problematic village. In 2004 the Bali Pekraman Assembly was formalized after the enactment of a regional regulation on the village of pakraman. In his report, Windia, the Chairperson of the Steering Committee (MUDP) of Bali explained a number of excellent programs to be pioneered. Among other things, fighting for Pekraman villages as formal legal subjects in accordance with the national Law, and fighting for the settlement of customary cases to obtain the legitimacy of the state justice institutions. An interview on 24 May 2017 with Asmara Jaya as the Head of Pakraman Pempatan Village explained that freeing Pakraman village wealth from the 
obligation to pay taxes, and proposing for adat law as compulsary subjects at junior and senior high school are still in the process. Customary cases that have been decided in the village such as inheritance rights are sometimes canceled by the court. This must be synergized so that adat (customary) law has authority, explained Windia. Windia pushed for more civilized customary law because of many challenges faced by Hindus in Bali. For example, the internal problems of traditional villages such as physical and material obligations, called ayahan desa are the same without regard to the economic conditions of residents. External problems identified include entrepreneurs who ignore customary norms, conflicts in villages due to globalization and loss of the spirit of togetherness. The law that was just issued concerning traditional village in 2014 passed by President Susilo Bambang Yudhoyono is indeed something special. Government Regulation (PP) Number 43 Year 2014 concerning Regulations for Implementing Law Number 6 Year 2014 concerning Villages. The issuance of the Regulation on the Implementation of the Law on Villages is based on considerations to implement a number of provisions in Law Number 6 Year 2014 concerning Villages, as well as to optimize the implementation of village governance. The existence of the authority of the village led to the adat village institutions, Bali still maintains a number of customary sanctions for the indigenous people. This punishment is outside of formal punishment such as criminal. Adat law only covers issues that surround the rights and obligations of indigenous people in Bali. The hindu Balinese as a member of banjar will get fined when they don't go to the banjar adat meeting of doing social service. To a certain extent, sanctions are more stringent adat, and the climax is Kasepekang.

Several cases of kasepekang that have existed in Bali include cases of Banjar Pakudui residents, Pakudui Village, Tegalalang, Gianyar, Made Rangga being subjected to Kasepekang sanctions by the banjar. As a result of this sanction, when his father passes away, the late Mangku Sunil who was also the holder of Puseh Pakudui Temple, Made Rangga was charged with the obligation to pay a fine of 3,200,000 IDR. Another case is a resident of Banjar Labak, Anturan Village, Singaraja, Nyoman Sumatra. He is subject to a Kasepekang sanction by Pakraman Village, which was preceded by land claims. This case finally rolled to city court of Singaraja ended in a criminal sentence of 1.5 years imprisonment with an 8-month probation sentenced to Kelian Desa Pakraman Anturan. In its development despite a court ruling, the Kasepekang criminal was still imposed on the family. An interview carried out on April 15, 2017 with I Wayan Berata Kelian, Adat Pempatan Village, Rendang Subdistrict, Karangasem Regency stated that the arrangement of suspect I Wayan Katriana, who had never participated in traditional activities such as never engaging, never pay village fees used for traditional ceremonial activities. It is still not being or paid. An interview on May 24, 2017 with I Gede Endi Susila explained that even if there is a problem, the background or root of the problem must be seen. Because the person concerned did not want to resolve and conduct village meeting (paruman) to solve the problem. According to Paruman and traditional leaders, as well as community representatives based on Awig-awig (articles on adat law) Number 18, paragraph 14 regarding unwritten regulations, were decided by the village paruman meeting Pakraman Pempatan and agreed to implement kasepekang sanctions. The case is that the civil problem continues with action and reaction, developing into a criminal problem. Because Kasepekang is from the adat law, the solution must be seen for settlement; everything is decided against the higher laws apply in this country. Based on the decision of village meeting (paruman), it does not mean that everything is decided by paying a fine of Rp. 200 million. It is only an agreement. The meeting also decide invite the kasepekang people to sit together to discuss deliberation.

An interview on May 2, 2017 with Mangku Widana admitted stroking his chest to hear this problem. When the concept of desa (place), kala (time), and patra (condition) is a blank check, the sanction of 200 million IDR is killing and make miserable both physically and mentally to the member of the banjar who sentence with kasepekang sanctions. It might be better for them to transmigrate or convert to other religions. It is hoped that the PHDI should make a general concensus (bhisama) like a statement of manak salah (giving birth of twin brother or sister) which is no longer exist. An interview on May 2, 2017 with Ngurah Arya as Kelian Desa expressed concern and asked why the person in question did not want to apologize and deliberate so that they would not be subject to Kasepekang customary law. Balinese people are very strict in their regulations. It's not like that from outsiders. They get along better, we fight more. An interview on 27 May 2017 with Gede Darmawan, a community leader in Pakraman Pempatan Village, stated that due to traditional violations in Pakraman village, it was very ironic that 
our fellow Balinese fight and dropped down each other. Kasepekang in principle is a sanction that has a social dimension in which a family or a family group will be excluded from being a member of the banjar or village community. This reality is very far or not touched by positive law in force. In the case of Kedungu, which is said to have caused pollution involving a place, the banjar felt it was right to give sanction by being excluded from the banjar. This problem requires a special court, a kind of religious court, but a court for hindu religion is not yet exist. Kesepekang sanction is merely done base on social emotion. The authority of village officers in imposing sanctions on Kasepekang must hold a meeting at the level of village officers. Then, the result would be announced at the Sabu Village Meeting. Legal consequences may arise if the village officers are proven to be arrogant or arbitrary, they can be given sanctions such as (1) warning, (2) reprimand, and (3) dismissed as village officers. Veiwing from the laws and regulations, there are indications that village officers have violated Law Number 39 Year 1999 concerning Human Rights (HAM) specifically Article 1 paragraph 3, as well as violating the decision of the main assembly of the Bali Pakraman Village Assembly Number: 01 / Kep / Psm-2 / MDPBali / X / 2007.

As a customary law community unit, Desa Adat is bound by customary law that grows and develops within the local community, better known as awing-awig. It is the basic guideline of the Pekraman village in its administration. Awig-awig contains rules that are regulating and forcing the community to create harmony in every legal relationship in the community. The awig-awig are made and determined by villagers based on mutual agreement and obeyed by all members of the village and the most important thing is that the awig-awig are the binder of the unity and integrity of village to ensure the cohesiveness and integrity in uniting common goals, realizing a safe, peaceful, orderly life and prosperous for the peace of the village. Adat sanction is an effort to restore this balance. In 2007, the Bali Pakraman Village Assembly issued Decree Number 01 / Kep / Psm 2 / MDP Bali / X / 2007 stating that, "Imposition of adat sanctions for kasepekang and kanorayang (temporarily banned from village life involment) should be postponed until there is an adequate formulation of the understanding and procedures for imposing sanctions the custom, which applies to all desa adat (traditional customary village) in Bali ". Cases of an isolation from indigenous villages are a tragedy, and this only exists in Bali. Other indigenous peoples in the archipelago have never known this kind of legal model of social punishment. Many Balinese do not understand who should solve this problem. In the Pakraman Pempatan Village, Rendang Karangasem regency, which treats adat law severely, the community members are prohibited from speaking to people who are in Kasepekang. In Bali adat sanctions have a very important role to restore the disturbed balance. The objective of the Witness (criminal) according to the adat concept is to restore the cosmic balance, the balance between the born world and the unseen world, to bring a sense of peace between fellow citizens.

\section{CONCLUSION}

An agreement of sanctions can be imposed based on paruman (meeting) pakraman village to the member of the banjar (local community) who have proven convincingly to disobey (ngatuwel) against awig-awig, pararem (meeting agreement), and other village consencus resulted from banjar agreemen. After some efforts of settlement through kertha desa (village officer) are fail, several other sanctions which were also imposed based on village meeting (paruman). These other sanctions may include verbal and written warning by banjar or pakraman village officer and arta danda (material fine) based on the prevailing regulations.

The implementation of adat sanctions applies for a maximum period of 3 (three) Paruman Pakraman villages which are scheduled for discussion regarding the imposition of sanctions. If in the period of 3 (three) paruman (meeting of village officers), the party who is subject to sanctions does not fulfill all obligations imposed, then the person concerned can be dismissed (kanorayang) as a village member. They are not entitled to use all the facilities belonging to the village, unless the person concerned fulfill all the requirements in accordance with the applicable awig-awig (articles prescribed on adat law).

Based on the description of the conclusions outlined above it can be suggested that the village leaders of Pakraman Pempatan, Rendang Subdistrict, Karangasem Regency continue and increase the tolerance sense for fellow citizens and migrants. This is to emphasize that it is considered bad when Balinese people fight each other in the community and villagers of Desa Pakraman Pempatan map problems 
arised from adat conflicts by anticipating the era of globalization to be able to stay away from kasepekang adat sanctions.

\section{REFERENCES}

Ali, M., \& Asrosi, M. (2014). Metodologi dan Aplikasi Riset Pendidikan. Jakarta: PT. Bumi Aksara

Astiti, T. I. P. (2010). Desa Adat Menggugat Dan Digugat. Bali: Udayana University Press

Bakri, M. (2011). Pengaturan Hukum Indonesia (Sistem Hukum Indonesia Pada Era Reformasi). Malang: Universitas Brawijaya Press

Fakultas Hukum Universitas Udayana. (2013). Pedoman Pendidikan Fakultas Hukum Universitas Udayana, Denpasar

Kansil. (2008). Pengantar Ilmu Hukum. Jakarta: Balai Pustaka

Masriani, Y. T. (2004). Pengantar Hukum Indonesia. Jakarta: Sinar Grafika

Machmudin, D. D. (2003). Pengantar Ilmu Hukum. Bandung: Refika Aditama

Nasution, S. (2014). Metode Research (Penelitian Ilmiah). Jakarta: Bumi Aksara

Rahardjo, S. (2012). Ilmu Hukum. Bandung: Citra Aditya Bakti.

Rato, D. (2009). Pengantar Hukum Adat. Yogyakarta: LaksBang PresSindo

Sirtha, I. N. (2008). A spek Hukum Dalam Konflik Adat di Bali. Bali: Udayana University Press

Sunggono, B. (2007). Metode Penelitian Hukum. Jakarta: PT. Raja Grafindo

Suryabrata, S. (2004). Metode Penelitian. Jakarta: PT. Raja Grafindo Persada

Soeroso. (2011). Pengantar Ilmu Hukum. Jakarta: Sinar Grafika

Syarifin, Pipin., \& Chumaidy, Z. (1998). Pengantar Ilmu Hukum. Bandung: Pustaka Setia

Undang-undang Nomor 1 Tahun 1951 tentang kedudukan hukum pidana

Undang-Undang Nomor 6 Tahun 2014 Tertang Desa.

Undang-Undang Nomor 43 Tahun 2014 Tertang Peraturan Pelaksanaan Undang-Undang Nomor 6 Tahun 2014.

Peraturan Pemerintah Nomor 72 Tahun 2005 tentang Pembentukan Desa.

Utrecht, E. (1966). Pengantar Dalam Hukum Indonesia. Jakarta: Penerbit Balai Ichtiar

Windia, W. P. (2006). Pelaksanaan Sanksi Adat Kasepekang di Desa Pakraman. Makalah dalam Semiloka tentang Sanksi Adat Kasepekang yang diselenggarakan Bali Shanti LPM Unud, Denpasar

Windia, W. P. dan Sudantra Ketut. (2006). Pengantar Hukum Adat Bali. Denpasar: Lembaga Dokumentasi dan Publikasi Fakultas Hukum Universitas Udayana

Windia, W. P. (1995). Menjawab Masalah Hukum. Bali: Udayana University Press

Wiratna, S. (2012). Konstitusi Ekonomi. Denpasar: Udayana University Press 